\title{
Program Pengembangan Desa Mitra Siaga Komorbid Era New Normal di Wilayah Kerja Puskesmas Jambi Kecil
}

\author{
Arvida.Bar $^{1}$, Kaimuddin ${ }^{2}$, Nur Insani ${ }^{3}$ \\ 1-3 Jurusan Keperawatan, Poltekkes Kemenkes Jambi \\ Email: arvidabar68@yahoo.ac.id
}

Submitted : 22/01/2022

Accepted: $23 / 01 / 2022$

Published: 28/01/2022

\begin{abstract}
In this normal new era, where comorbid is in the spotlight due to the death rate of Covid-19 disease is usually accompanied by the condition of a heretic. Proper methods of controlling and cutting off the chain of infection can include $3 M$ (wearing masks, washing hands, walking distance) in everyday life. The goal of creating a partnership between stakeholders (center head, village head), is to increase knowledge of education and training of cadence and health-care professionals. It was supported by village headmen center chiefs and community leaders. It also greatly helps communities learn about their health and condition during the Covid-19 pandemic and increases their understanding in efforts to prevent the spread of Covid-19 diseases in society. The results of an evaluation of improved public knowledge assessment and Kader. Assessments from the questionnaires are shown increasing knowledge from communities impervious to land dung, waterproofing daffs, and lakes. The devotion of this society resulted in increased knowledge and attitude in the pathological and societal preparedness of the Covid-19 infection in the region of the minor Jambi office, the increased behavior of Kader to try together to prevent the transmission of Covid-19 especially to the morphing grouping of the groupings in the impervious aged lake village, land retards, and refunds.
\end{abstract}

Keywords: covid, erderly, komorbid, new normal

\begin{abstract}
Abstrak
Di era new normal ini, dimana komorbid menjadi sorotan dikarenakan angka kematian penyakit Covid-19 biasanya disertai dengan kondisi komorbid. Pengendalian dan pemutusan mata rantai penularan tersebut dapat dilakukan dengan metode yang tepat antara lain dengan 3M (memakai Masker, Mencuci tangan, Menjaga jarak) di dalam kehidupan sehari-hari. Kegiatan pengabdian masyarakat ini bertujuan agar terbentuknya kerjasama mitra antara stakeholder (kepala puskesmas, kepala desa), melaksanakan peningkatan pengetahuan berupa penyuluhan kepada masyarakat dan pelatihan kader serta pemeriksaan kesehatan lansia. Kegiatan ini mendapat dukungan dari Kepala Desa dan Kepala Puskesmas serta tokoh masyarakat. Kegiatan ini juga sangat membantu masyarakat untuk mengetahui kesehatan dan kondisi mereka selama masa pandemi Covid-19 serta meningkatkan pemahaman mereka dalam upaya pencegahan penularan penyakit Covid-19 di masyarakat. Hasil evaluasi berupa penilaian peningkatan pengetahuan masyarakat dan kader. Hasil penilaian dari kuesioner didapat adanya peningkatan pengetahuan dari masyarakat di desa Mudung Darat, Bakung dan Danau Kedap. Pengabdian Masyarakat ini menghasilkan adaya peningkatan pengetahuan dan sikap kader dan masyarakat dalam upaya siaga komorbid dari penularan Covid-19 di wilayah kerja Puskesmas Jambi Kecil, adanya peningkatan perilaku kader untuk berupaya bersama dalam mencegah penularan Covid-19 terutama pada kelompok lansia yang komorbid di desa Danau Kedap, Mudung Darat dan Bakung. Dengan adanya kegiatan ini diharapkan masyarakat mengetahui dan memahami bagiamana upaya pencegahan Covid-19 di masyarakat. Sehingga dapat diterapkan dalam kehidupan sehari-hari di dalam kegiatan masyarakat, diharapkan kader bisa menerapkan upaya pencegahan penyebaran virus Covid-19 dimasyarakat sehingga dapat membantu pemerintah dalam penurunan jumlah kasus Covid-19 di Kabupaten Muaro Jambi.
\end{abstract}

Kata Kunci: covid, lansia, komorbid, new normal 


\section{PENDAHULUAN}

Komorbid diartikan

penyakit penyerta; sebuah istilah dalam dunia kedokteran yang menggambarkan kondisi bahwa ada penyakit lain yang dialami selain dari penyakit utamanya. Dalam Bahasa Indonesia sederhana sama artinya dengan komplikasi (medis), yaitu kondisi di mana dua penyakit atau lebih hadir secara bersama-sama. Istilah komorbid ini sering didengar pada masa pandemi Covid-19. Seseorang dengan komorbid disebut sebagai berisiko mengalami kondisi parah ketika terinfeksi virus corona. Pada pasien infeksi virus corona, salah satu kondisi umum yang ditemukan adalah memiliki komorbid. Komorbid terkadang dianggap sebagai diagnosis sekunder dan telah dikenali setelah perawatan untuk diagnosis utama. Pasien dengan komorbid memiliki tingkat mortalitas yang lebih tinggi dari pada pasien biasa. Paparan Covid-19 pada individu komorbid, seperti penderita diabetes, dapat memengaruhi paru-paru, jantung, ginjal, dan hati. Dalam sebuah penelitian, komorbid yang paling umum pada pasien Covid-19 adalah diabetes, kardiovaskular, dan penyakit sistem pernapasan.

Di era new normal ini, dimana komorbid menjadi sorotan dikarenakan angka kematian penyakit Covid-19 biasanya disertai dengan kondisi komorbid. Adapun bentuk-bentuk upaya saat ini dilakukan dalam masyarakat antara lain : a.Upaya meningkatkan / promosi kesehatan Upaya meningkatkan kesehatan promotif pada dasarnya merupakan upaya mencegah primer (primary prevention). b.Peningkatan ketakwaan terhadap Tuhan Yang Maha Esa. c.Peningkatan kesehatan dan kebugaran lanjut usia, d.Peningkatan ketrampilan kesenian, hiburan rakyat dan rekreasi merupakan kegiatan yang sangat diminati oleh lanjut usia, e.Upaya pencegahan/prevention. Kegiatan ini dilaksanakan pada tiga desa yakni Desa Mudung Darat, Desa Bakung dan Desa Danau Kedap. Desa tersebut dipilih karena di tiga desa tersebut terdapat jumlah kasus Covid yang cukup tinggi dibandingkan desa yang lain dalam satu wilayah kerja Puskesmas Jambi Kecil dan jarak dari ketiga desa tersebut berdekatan. Kecamatan Maro Sebo merupakan wilayah kerja Puskesmas Jambi Kecil, Kabupaten Muaro Jambi merupakan daerah dengan kasus Covid-19 yang cukup tinggi.

Adapun masalah yang terjadinya peningkatan kasus komorbid yang terpapar Covid-19 di Puskesmas Jambi Kecil yang beresiko kematian pada lansia: masih rendahnya pemahaman masyarakat tentang kepatuhan 3M, masih rendahnya tingkat pengetahuan dan partisipasi masyarakat sehingga pemahaman terhadap faktor resiko pada lansia yang komorbid rendah bila terpapar virus Covid-19, adanya pemahaman bahwa pencegahan di masyarakat adalah tugas tenaga kesehatan saja sehingga partisipasi masyarakat dalam kesiagaan kesehatan lansia kurang diperhatikan.

Terlaksananya kegiatan pengabdian masyarakat siaga komorbid Era New Normal di Wilayah Kerja Puskesmas Jambi Kecil Kabupaten Muaro Jambi bertujuan untuk melakukan sosialisasi gerakan siaga komorbid dan 3M (Pakai Masker, Mencuci tangan dan Menjaga jarak) berupa peningkatan pengetahuan masyarakat sebagai upaya pencegahan Covid-19, adanya pembinaan kader dalam upaya pencegahan resiko tertular dan penanggulangan Covid-19 pada lansia dengan cara pemberian pelatihan kader lansia, dilakukannya pemeriksaan kesehatan pada lansia melalui kegiatan pemantauan kesehatan lansia di posyandu lansia. 
Manfaat dari kegiatan dari hasil evaluasi didapatkan meningkatnya pengetahuan tentang siaga komorbid, masyarakat dapat mengetahui cara pencegahan penularan Covid-19 di masyarakat, membantu puskesmas dalam upaya penyampaian informasi tentang upaya yang dapat dilakuan dalam memutus mata rantai penularan Covid-19 di wilayah kerja Puskesmas Jambi Kecil.

Sasaran kegiatan ini adalah kader dan anggota Posyandu lansia di desa Mudung Darat, desa Bakung dan desa Danau Kedap. Pelatihan ini dimaksud agar peserta memahami memahami resiko bahayanya penularan Covid-19 bagi lansia terutama yang memiliki comorbid, sehingga mereka dapat menerapkan upaya-upaya promotiv dan preventif dalam keluarga dan masyarakat, selain itu dapat memantau dan mengetahui kondisi kesehatan lansia yang ada di desa-desa tersebut, sehingga dapat menjadi bahan informasi kesehatan yang bermanfaat bagi lansia dan Puskesmas Jambi Kecil.

Sasaran lain dari kegiatan ini mitra yaitu Puskesmas, Kepala Desa dan tokoh tokoh di masyarakat, sehingga terjalin kerjasma yang baik antara pendidikan dan stakeholder khususnya Puskesmas Jambi Kecil, Desa dan tokoh masyarakatnya.

\section{TARGET DAN LUARAN}

Target capaian dari kegiatan ini adalah adanya pemahaman stakeholder terhadap upaya pencegahan Covid-19, adanya pemahaman masyarakat desa tentang gerakan 3M dan upaya pencegahan Covid19 pada lansia, adanya pemahaman kader tentang komorbid dan resiko penularan Covid-19, mendapatkan hasil ukur kesehatan masyarakat, meningkatnya pengetahuan dan sikap masyarakat yang diwujudkan dengan perilaku pencegahan Covid-19 dan keberlanjutan pelaksanaan 3M didalam setiap kegiatan masyarakat

Luaran yang didapatkan adalah adanya dukungan kebijakan dari stakeholder dalam keberlangsungan kegiatan tersebut dan kesepakatan pelaksanaan Gerakan 3M, dukungan dari masyarakat untuk sepakat melaksanakan gerakan 3M dalam upaya pencegahan penularan Covid-19 di desa, dukungan dan partisipasi aktif kader dan sepakat untuk melaksanakan upaya-upaya promotiv dan preventif dalam upaya pencegahan penularan Covid-19 pada lansia komorbid, didaptnya informasi kesehatan berupa hasil pemeriksaan kesehatan lansia sehingga masyarakat merasa terbantu dengan adanya kegiatan pemeriksaan kesehatan gratis dalam kegiatan posyandu lansia di ketiga desa tersebut

\section{METODE PELAKSANAAN}

Kegiatan dilakukan selama $3 \mathrm{x}$ seminggu selama 2 minggu berturut - turut dengan berbagai kegiatan, yaitu

1. Pendekatan kepada pemerintah setempat yaitu stakeholder di Desa, Puskesmas Jambi Kecil dan juga petugas kesehatan yang ada di wilayah Puskesmas Jambi Kecil dengan tujuan akan dapat meningkatkan partisipasi masyarakat yang difasilitasi oleh Bidan Desa dan kader Posyandu Lansia.

2. Melakukan pertemuan advocacy dan koordinasi dengan Pimpinan Puskesmas Jambi Kecil, Kades, dan Bidan Desa (Mudung Darat, Bakung, dan Danau Kedap), Kader yang dibina dalam mensosialisasikan kegiatan tersebut.

3. Melakukan penyusunan rencana kerja dan jadwal kegiatan yang disepakati disesuaikan dengan kondisi dan situasi mitra.

4. Melakukan pelatihan kader Desa Siaga Comorbid dan membuat perencanaan kegiatan bersama kader

5. Serta melakukan pemantauan kesehatan lansia melalui kegiatan posyandu lansia yang dilaksanakan oleh Desa Mudung dara, Desa Bakung dan Desa Danau Kedap

Kegiatan pelatihan dilaksanakan di tiga desa yaitu Desa Danau Kedap, Mudung Darat dan Desa Bakung, dengan jumlah 
peserta kegiatan adalah \pm 100 orang peserta. Dikarenakan kondisi pandemi maka pelaksanaan dilakukan secara bertahap di ketiga desa tersebut dengan memperhatikan protokol kesehatan secara ketat. Semua peserta, narasumber, pelaksana pengabdian masyarakat yang terdiri atas dosen, mahasiswa dan tamu undangan yang hadir semua memakai masker dan mencuci tangan sebelum masuk keruangan serta dilakukan cek suhu badan. Tempat duduk peserta diberikan jarak dan dihimbau mengurangi interaksi antar peserta.

\section{HASIL DAN PEMBAHASAN}

1. Peningkatan pengetahuan dan sikap kader tentang upaya pencegahan Covid19 pada lansia

Tabel 1. Hasil Evaluasi Pengetahuan Kader

\begin{tabular}{ccc}
\hline No & Evaluasi & Rerata Nilai Evaluasi \\
\hline 1 & Sebelum & 60 \\
2 & Sesudah & 97
\end{tabular}

Kegiatan pelatihan kader di Desa Danau Kedap, Mudung Darat dan Bakung, terlihat sebelum kegiatan masih banyak kader memiliki pengetahuan dan sikap yang masih rendah terhadap upaya pencegahan Covid-19 ini terlihat pada hasil rerata nilai pengetahuan 60, setelah pemberian pelatihan terjadi peningkatan pengetahuan kader yakni pengetahuan 97 (sangat baik).

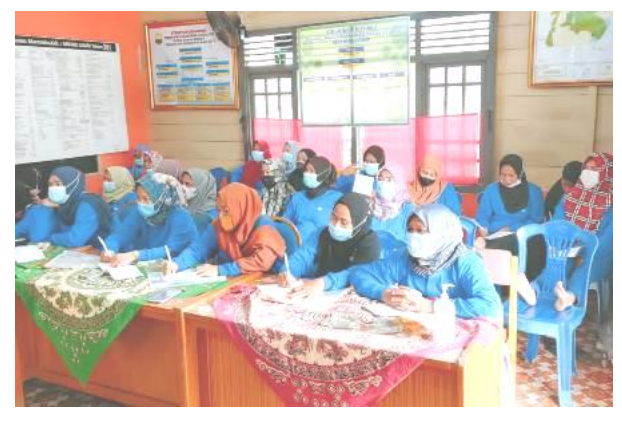

Dalam kegiatan pelatihan tersebut, kader sangat antusias dan berterimah kasih karena mendapatkan ilmu pengetahuan tentang Covid-19 secara langsung dari petugas kesehatan, selama ini mereka hanya tahu dari pemberitaan media massa, selainn itu mereka juga akan akan melaksanakan protokol kesehatan dalam kegiatan apapun sehari-hari sehingga mereka nantinya terhindar dari penularan virus Covid-19 tersebut.

2. Peningkatan pengetahuan dan sikap masyarakat tentang bahaya Covid-19 serta upaya pencegahannya di masyarakat

Kegiatan peningkatan pengetahuan masyarakat tentang upaya pencegahan Covid-19 dikarenakan dalam kondisi pandemi maka dilaksanakan secara bertahap. Hasil peningkatan pengetahuan masyarakat desa adalah:

Tabel 4.2. Peningkatan Pengetahuan Masyarakat Desa Tentang Upaya Pencegahan Covid-19

\begin{tabular}{|c|c|c|c|c|}
\hline \multirow[t]{2}{*}{ No } & \multirow[t]{2}{*}{ Evaluasi } & \multicolumn{3}{|c|}{ Nilai Rerata Pengetahuan } \\
\hline & & $\begin{array}{l}\text { Danau } \\
\text { Kedap }\end{array}$ & Mudung & Bakung \\
\hline 1 & Sebelum & 60 & 56 & 56 \\
\hline 2 & Sesudah & 97 & 88 & 85 \\
\hline
\end{tabular}

Pelatihan pengetahuan masyarakat tentang upaya pencegahan Covid-19, juga terlihat peningkatan pengetahuann yang signifikan. Hampir seluruh masyarakat menyatakan bahwa mereka banyak mendapatkan ilmu pengetahuan tentang Covid-19 dan pencegahannya, mereka juga menyatakan akan melaksanakan gerakan pencegahan penularan penyakit Covid-19, agar mereka selalu sehat.

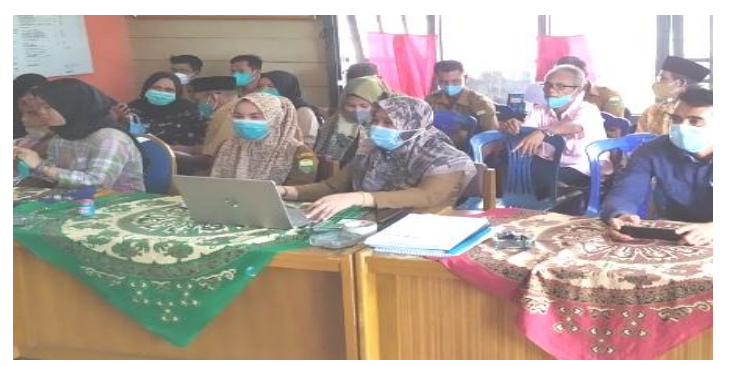




\section{Pemeriksaan kesehatan lansia}

Pelaksanaan kegiatan pemeriksaan kesehatan lansia bertepatan dengan pelaksanaan posyandu lansia di Desa. Kegiatan ini melibatkan petugas kesehatan puskesmas. Hasil pemeriksaan kesehatan lansia dicatat oleh petugas kesehatan dan disampaikan kepada lansia. Jika terdapat nilai pemeriksaan diatas normal, maka lansia dianjurkan untuk berkonsultasi kesehatan ke Puskesmas Jambi Kecil sebagai tindak lanjut dari hasil pemeriksaan kesehatan tersebut. Kegiatan ini sangat diterima masyarakat dalam kegiatan posyandu lansia, karena mereka mendapatkan pelayanan pemeriksaan kesehatan gratis dari petugas kesehatan.

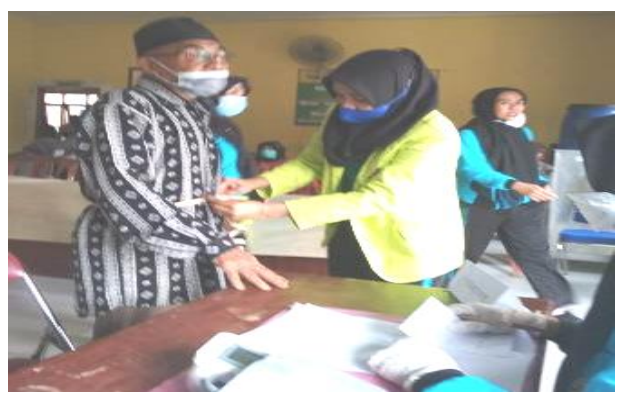

\section{KESIMPULAN DAN SARAN}

\section{Kesimpulan}

Terjadi peningkatan pengetahuan dan sikap kader dan masyarakat dalam upaya siaga komorbid dari penularan covid-19, adanya peningkatan perilaku kader untuk berupaya bersama dalam mencegah penularan covid-19 terutama pada kelompok lansia yang komorbid , terlaksananya kegiatan pemeriksaan kesehatan dan pemantauan kesehatan pada lansia di Posyandu lansia, serta adanya dukungan dari stakeholder (kepala puskesmas, kepala desa, bidan desa serta tokoh masyarakat) sehingga seluruh kegiatan dapat berjalan dengan baik.

\section{Saran}

Hendaknya masyarakat dapat menerapkan perilaku pencegahan Covid-19 dalam kehidupan sehari-hari. Dengan kegiatan pelatihan kader, kader bisa menerapkan upaya pencegahan penyebaran virus Covid-19 dimasyarakat sehingga dapat membantu pemerintah dalam penurunan jumlah kasus Covid-19 di Kabupaten Muaro Jambi.

Bagi Puskesmas Jambi Kecil, dikarenakan kondisi pandemi Covid-19, diharapkan pemantauan kesehatan masyarakat serta upaya-upaya memutus mata rantai penularan Covid-19 lebih ditingkatkan sebagai upaya program siaga Covid-19.

\section{UCAPAN TERIMAKASIH}

Keberhasilan dan kelancaran Kegiatan pengabdian masyarakat yang berbentuk pelatihan kepada kader dan anggota posyandu lansia ini, tak lepas dari dukungan berbagai pihak, untuk itu kami ucapkan terimakasih atas semua bantuan, baik materil dalam bentuk dana, fasilitas, waktu yang disediakan serta moril kepada:

1. Direktur Poltekkes Kemenkes Jambi

2. Kepala Puskesmas Jambi Kecil, Kepala Desa Mudung, Danau Kedap, bakung, Bidan Desa, Kader serta Masyarakat Wilayah Kerja Puskesmas Jambi Kecil Kabupaten Muaro Jambi

3. Serta Berbagai pihak yang tidak bisa disebutkan namanya

\section{DAFTAR PUSTAKA}

Dinkes Prov. Jambi, Data Penyebaran Covid-19 Provinsi Jambi, http://dinkes.jambiprov.go.id

Direktorat Promkes, 2020, Adaptasi Kebiasaan Baru, Kementerian Kesehatan RI

Kemeristek Dikti, 2018, Panduan Penelitian dan Pengabdian kepada Masyarakat Edisi XII, Direktorat Jenderal Penguatan Riset dan Pengembangan Kemenristek Dikti 2018 
Kementerian PPN / Bappenas, 2021, Satgas Covid, Penanganan Kesehatan (3M), Panduan Protokol Penelitian dan https://covid-19.go.id

Pengmas di masa Pandemi Covid-19

dan Kondisi Kedaruratan Lainnya untuk Adaptasi Kenormalan Baru, https://k.si-indonesia.org

PPSDM Kesehatan RI, 2018, Pedoman Pengabdian Kepada Masyarakat Tahun 2018, Kemenkes RI

Pemda Prov. Jambi, Data Covid-19 Provinsi Jambi, https://corona.jambiprov.go.id

Satgas Covid, Data Covid-19 (update November 2021), https://covid19.go.id 